Open Access

\title{
Entrepreneurial intention, job satisfaction and organisation commitment - construct of a research model through literature review
}

\author{
Kh. Devananda Singh * (1) and B. D. Onahring
}

* Correspondence:

devananda.singh@yahoo.com

Department of Management, North-Eastern Hill University, Tura Campus, Tura, Meghalaya 794002, India

\begin{abstract}
Intention is a human behavior. Measurement of intention in terms of entrepreneurial mindset is becoming a researchable topic. During the past years, the factors namely lack of fund, lack of raw materials, unskilled employees etc. were mostly considered to be the deterrents of initiation and development of entrepreneurial activities. But, with the various development provisions are made by the concern authorities, it leads to the emergence of entrepreneurial intention as an important factor. The present paper is a humble effort to develop a research model of the relationship between entrepreneurial intention, job satisfaction and organisation commitment.
\end{abstract}

Keywords: Entrepreneurial intention, Job satisfaction, Organisation commitment and Research model

\section{Introduction}

Entrepreneurial intention is the feeling of having one's organisation that is derived from personal and contextual factors Bird, (1998). Ajzen (1991) portrays that the decision to start a new firm is assumed to be planned for some time and thus preceded by an intention to do so. However, in some cases this intention is formed only shortly before the actual decision and in some cases the intention never leads to actual behaviour. Hence, entrepreneurial intentions are assumed to predict individual's choice to found their own firms. Psychological research shows that intention is a crucial predictor of subsequent planned behaviour (Bagozzi et al., 1989). Consequently, entrepreneurial intention is a decision to form a new business venture that is planned rather than being conditioned. An individual may have the potential of being entrepreneur because of own competency and self-efficacy but may not make the transition into entrepreneurship because of the lack of intention (Krueger Jr et al., 2000).

Job satisfaction is a combination of any psychological, physiological and environmental circumstances that cause a person truthfully satisfied with the job (Hoppock, 1935). Vroom (1964) opined that job satisfaction mainly focuses on the role of the employee in the workplace. He defined job satisfaction as an affective orientation on the part of individuals toward work roles which they are

(c) The Author(s). 2019 Open Access This article is distributed under the terms of the Creative Commons Attribution 4.0 International License (http://creativecommons.org/licenses/by/4.0/), which permits unrestricted use, distribution, and reproduction in any medium, provided you give appropriate credit to the original author(s) and the source, provide a link to the Creative Commons license, and indicate if changes were made. 
presently occupying. Job satisfaction represents the extent to which expectations are and match the real awards. Job satisfaction is closely linked to that individual's behaviour in the work place (Davis \& Nestrom, 1985). Spector (1997a, b) articulated that job satisfaction has to do with the way how people feel about their job and its various aspects. It has to do with the extent to which people like or dislike their job and has been associated with numerous psychosocial issues namely the changing world of work, organisational factors, ranging from leadership to job design. In a scholarly academic contribution, Statt (2004) defined job satisfaction as the extent to which a worker is content with the rewards he or she gets out of his or her job, particularly in terms of intrinsic motivation. Job satisfaction is one of the most researched variables in the area of workplace psychology (Lu et al., 2012). Singhai (2016) opined job satisfaction as the evaluation of person's job and his company as contributing suitably to the attainment of one's personal objectives. The job satisfaction and dissatisfaction depends on the nature of job and also on the expectation from their job. Therefore, it is a function of the intended and actual performance and the perceived discrepancy. The concept of job satisfaction can be defined as the difference between the quantum of rewards received by employees and the amount they believe they should receive.

On the other hand, organisational commitment is the employees' state of being committed to assist in the achievement of the organisation's goals and involves the employees' levels of identification, involvement, and loyalty (Caught \& Shadur, 2000). It is a state of being, in which organisational members are bound by their actions and beliefs that sustain their activities and their own involvement in the organisation (Miller \& Lee, 2001). Again, Miller (2003) highlighted organisational commitment as a state in which an employee identifies with a particular organisation and its goals and wishes to maintain membership in the organisation. It is therefore, the degree in which an employee is willing to maintain membership due to interest and association with the organisation's goals and values.

The main focus of this paper is to develop a research model on the relationship between entrepreneurial intention, job satisfaction and organisational commitment through relevant review of literature. The contribution to the existing literature and the implications of the model developed in this paper may include:

a. The development of co-relationship between entrepreneurial intention, job satisfaction and organisational commitment and

b. The application of the model in further research studies which are having the similar variables discussed in this paper.

The time period of this paper is 1977 to 2018 as the review of literature was made on the literature developed during this period.

\section{Methods}

\section{Aim of the study}

The aim of the study is to construct a research model on the relationship between entrepreneurial intention, job satisfaction and organisational commitment. 


\section{Design and setting of the study}

In order to fulfil the aim of the study, the conceptual framework and review of literature are the important aspects of the paper. These are discussed in the following paragraphs:

\section{Conceptual framework}

In order to develop the research model, a conceptual framework on the above mentioned three variables has been framed as in the following paragraphs.

Entrepreneurial intention Remeikiene and Startiene (2013) highlighted that entrepreneurial intention as the growing conscious state of mind that a person desires to start a new enterprise or create new core value in existing organisation. Therefore, theories relating to "human intention" are the suitable theory(ies) to develop the conceptual framework of the paper. Bird (1988), on the other hand defined that entrepreneurial intention is the starting point of the decision to engage in any business or endeavour, making it a more important predictor of future entrepreneurial engagement compared to trait and demographic models (Katono et al., 2010).

\section{Theoretical perspectives of entrepreneurial intention}

The following paragraph discusses some of the relevant theories.

\section{Trait theory (Gordon \& Odbert, 1936)}

Gordon Allport was considered among the firsts to come up with a personality trait theory. In psychology, trait theory is an approach to study the personality of human beings. It is also known as dispositional theory. Trait theorists are primarily interested in the measurement of traits, which can be defined as habitual patterns of behavior, thought, and emotion (Saul, 2003). According to viewpoint of this theory, traits are aspects of personality that are relatively stable over time, differ across individuals, relatively consistent over situations and an influencing behavior.

\section{Need Theory (McClelland, 1961)}

David McClelland, in this theory, proposed that an individual's specific needs are acquired over time and are shaped by one's life experiences. He described three types of motivational need which are (a) need for power, (b) need for affiliation and (c) need for achievement. His need theory hypothesised that a person's effectiveness level and motivation is highly influenced by the above three needs.

\section{Goal-Setting theory (Locke, 1968)}

Locke (1968) proposed that intentions can be a major source of motivation and satisfaction. According to this theory, some specific goals (intentions) lead to increased performance. Furthermore, people will do better when they get feedback on how well they are progressing toward their goals as feedback identifies discrepancies between what have they done and what they want to do. 
The theory of reasoned action (Fishbein and Ajzen, 1975)

The theory was derived from previous research that began as the theory of attitude. The theory aims to explain the relationship between attitudes and behaviours within human action. Theory of Reasoned Action (TRA) is used to predict how individuals will behave based on their pre-existing attitudes and behavioural intentions. An individual's decision to engage in a particular behaviour is based on the outcomes the individual expects will come as a result of performing the behaviour (Rogers et al. 2002). In the words of Doswell et al. (2011) this theory serves to understand an individual's voluntary behaviour. The ideas found within the TRA have to do with an individual's basic motivation to perform an action. According to the theory, intention to perform certain behaviour precedes the actual behaviour (Azjen and Madden, 1986). This intention is known as behavioural intention and comes as a result of a belief that performs the behaviour which leads to a specific outcome. Behavioural intention is important to the theory because these intentions are determined by attitudes to behaviours and subjective norms (Colman, 2015). The following Fig. 1 shows the Model of TRA.

The model highlights that at the initial stage, intention is assumed to be used as a determinant of behaviour while at the second stage, attitude and subjective norm are included to explain the intention and on the last stage, attitude and subjective norm are explained in term of beliefs regarding the results in performing the behaviour and about the normative expectation of relevant referents.

\section{The theory of planned behaviour (Ajzen, 1985)}

The theory was developed from the Theory of Reasoned Action. The Theory of Planned Behaviour (TPB) postulates three conceptually independent determinants of intention. The first is the attitude toward the behaviour and refers to the degree to which a person has a favourable or unfavourable evaluation or appraisal of the behaviour in question. The second predictor is a social factor termed subjective norm; it refers to the perceived social pressure to perform or not to perform the behaviour. The third antecedent of intention is the degree of perceived behavioural control which refers to the perceived ease or difficulty of performing the behaviour and it is assumed to reflect past experience as well as anticipated impediments and obstacles. The following Fig. 2 shows the Model of TPB.

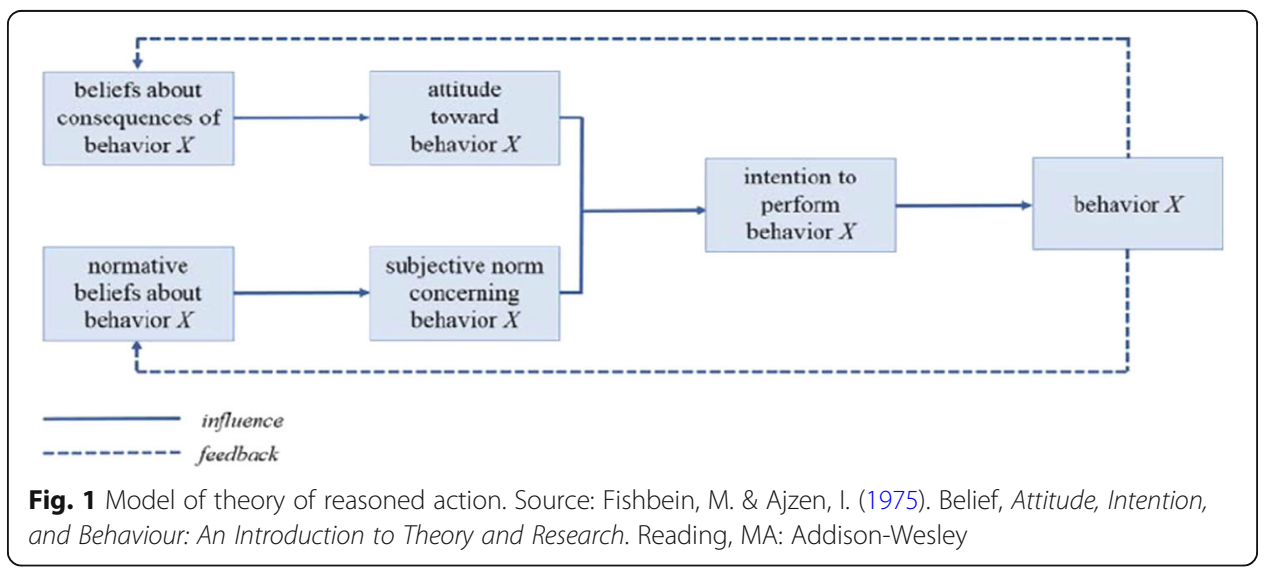




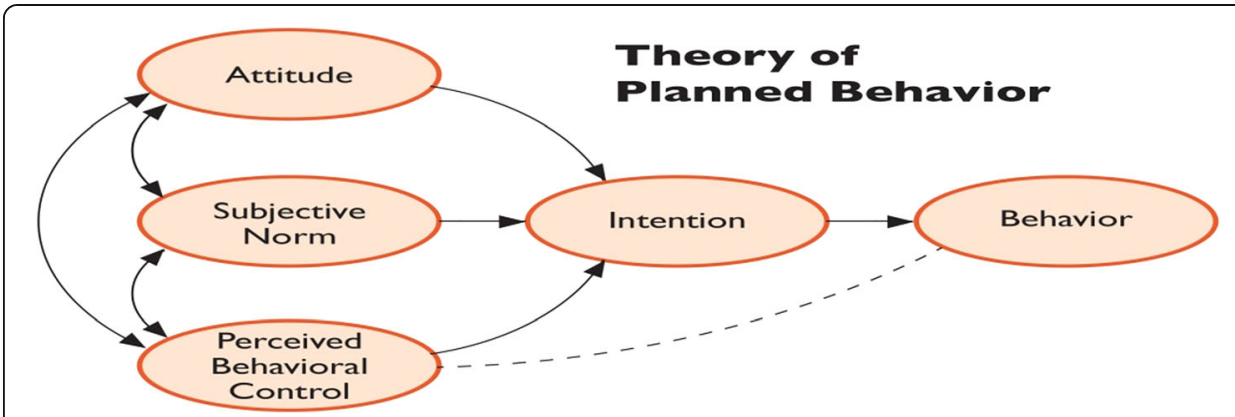

Fig. 2 Model of theory of planned behaviour. Source: Ajzen, I. (1991). Theory of Planned Behaviour, Organisational Behaviour and Human Decision Processes, 50 (2) 179-211

Job satisfaction The concept of job satisfaction traditionally has been of great interest to social scientists concerned with the problems of work in an industrial society (Spector, 1997a, b). A number of consequences have been shown to result from job satisfaction and dissatisfaction with respect to the workers' psychological well-being and with respect to the effective functioning of organisations. Of these, differences in measurement techniques are especially problematic since a multitude of indicators have been developed (Spector, 1997a, b) and it is questionable whether they all measure the same thing. So, research on job satisfaction is necessary to examine the different ways of measuring job satisfaction. Such knowledge would help researchers in assessing the dependence of their inferences regarding the causes and consequences of job satisfaction on the indicators they have used to measure the concept and would thus facilitate the comparison of research findings. Hackman and Oldham (1976) have postulated that the employee with high growth need strength would experience more job satisfaction than the employee with low growth need strength.

\section{Theories of job satisfaction}

Job satisfaction theories have a strong overlap with theories explaining human motivation. Shajahan and Shajahan (2004) classified the theories of job satisfaction into content theories and process theories. Content theories focus on identifying the needs, drives and incentives/goals and their prioritisation by the individual to get satisfaction and process theories are more concerned with how the motivation takes place (Luthans, 2005). Some of the relevant theories under these two categories are discussed below:

\section{Herzberg's two-factor theory (1959) - Content theory}

The theory is also known as Herzberg's motivation-hygiene theory or dual-factor theory which states that there are certain factors in the workplace that cause job satisfaction, while a separate set of factors cause dissatisfaction. Individuals are not content with the satisfaction of lower-order needs at work rather, individuals look for the gratification of higher-level psychological needs having to do with achievement, recognition, responsibility, advancement and the nature of the work itself. The presence of one set of job characteristics or incentives leads to workers' satisfaction at work, while another and separate set of job characteristics leads to dissatisfaction at work. Thus, satisfaction and 
dissatisfaction are not on a continuum with one increasing as the other diminishes, but are independent phenomena.

\section{Equity theory (Adams, 1963) - Process theory}

This theory suggests that employees ponder what they put into a job (input) against what they get from it (outcome) and then compare this ratio with the input-outcome ratio of other workers. If they find this ratio equal to that of the relevant others, a state of equity is said to exist (Robbins, 2005). It has been found that rewards increase employee satisfaction only when these rewards are valued and perceived as equitable by the employees (Perry et al., 2006).

\section{Vroom's expectancy theory (1964) - Process theory}

Vroom (1964) emphasised that people are motivated to work to achieve a goal if they believe that that goal is worthy and there is the probability that what they do will help them in achieving their goals. This theory is based on three major variables: valance, expectancy and instrumentality. Valance is the strength of an individual's preference (or value, incentive, attitude, and expected utility) for a particular output. Expectancy is the probability that a particular effort will lead to a particular first-level outcome while instrumentality is the degree to which a first-level outcome will lead to a desired second-level outcome. For example, a person can be motivated (motivational force or effort) toward better performance (first-level output) to realize promotion (second-level output) (Luthans, 2005).

\section{Job characteristics theory (Hackman and Odham, 1976) - Process theory}

Job characteristics are aspects of the individual employee's job and tasks that shape how the individual perceives his or her particular role in the organisation. Job characteristics theory argued that the outcomes of job redesign were influenced by several moderators. These moderators include the differences to which various employees desire personal or psychological progress (Perry et al., 2006).

Organisational commitment Organisational commitment refers to the employee's emotional attachment to, identification with and involvement in the organisation. In essence, measuring organisational commitment is an assessment of the congruence between an individual's own values and beliefs and those of the organisation (Swailes, 2002). Organisational commitment is characterised as employees' willingness to contribute to organisational goals. When employees are sure that they will grow and learn with their current employers, their level of commitment to stay with that particular organisation is higher (Okpara, 2004).

\section{Theories and model(s) of Organisational commitment}

\section{The side-bet theory (Becker, 1960)}

Becker (1960) described organisational commitment as a tendency to engage in consistent lines of activity and thus the effect of making side bets is to increase the cost of failing to persist in a course of action. The theory continues to be influential as a result of its incorporation into popular multi-dimensional models of organisational commitment (Powell \& Meyer 2004). 
Social identity theory (Tajfel, 1970)

Tajfel (1970) proposed that the groups such as social class, family etc. Which people belonged to were an important source of pride and self-esteem. Groups give a sense of social identity and a sense of belonging to the social world.

Burke and Stats (1998) advocated that social identity theory is having a greater emphasis on socio-cognitive processes, contextual responsiveness, group behaviour and intergroup relations and a clearer distinction between role and group. Social identity theory has concentrated on the causes and consequences of identifying with a social group or category and has focused more on the meaning associated with being a member of a social category. Again, Turner et al. (1994) have argued that because people defined themselves in terms of their social group membership and enact roles as part of their acceptance of the normative expectations of in group members.

\section{Meyer and Allen tri-dimensional model of organisational commitment (1997)}

This model conceptualise organisational commitment in three dimensions namely, affective, continuance and normative commitments. These dimensions describe the different ways of organisational commitment development and the implications for employees' behaviour. The dimensions of this model are:

a. Affective commitment which refers to affective commitment as the employee's emotional attachment to, identification with and involvement in the organisation.

b. Continuance commitment is based on Becker's (1960) side bet theory. Continuance commitment is a form of psychological attachment to an employing organisation that reflects the employee's perception of the loss he or she will suffer if they were to leave the organisation. Continuance commitment involves awareness on the employee's part of the costs associated with leaving the organisation.

c. Normative commitment reflects a feeling of obligation to continue employment. Employees with a high level of normative commitment feel they ought to remain with the organisation.

The foregoing discussions highlight the various relevant theories, instrument(s) and models that may be adopted for the construction of the research model. The reflection of the same is made in the following discussions.

\section{Review of literature}

A review of relevant literature has been made in the following themes.

Entrepreneurial intention The changes in attitudes with time provide the basic explanation or prediction of future action of individuals (Carlson, 1985). Knowing the intention and subsequent decision to create a new venture is an interesting issue to explore (Katz and Gartner, 1988).

In the words of Dell (2008); Dhose \& Waiter (2010) entrepreneurial intention is defined as willingness of individuals, to perform the behaviour of an entrepreneur, to engage in entrepreneurial action, to be self-employed and to establish new business 
ventures. Ismail et al. (2009) portrays that the study on entrepreneurial intention provides valuable insights to understand the process and predict entrepreneurial activities in better way. Krueger Jr et al. (2000); Krueger (2007) proposed that individual do not start a business as reflex but they do it intentionally rather than engage it accidentally. Entrepreneurial intention serves in defining the reasons on why certain individuals tend to start their own venture before opportunity scan or decided the type of business.

Turker and Senem (2009) empirically tested on a sample of 300 university students in Turkey through a model. The Entrepreneurial Support Model (ESM) considers predominantly the impact of contextual factors on entrepreneurial intention. In the model, entrepreneurial intention is taken as a function of educational, relational, and structural supports. The results of the study showed that educational and structural support factors affect the entrepreneurial intention of students.

Tong et al. (2011) studied on the perceptions of undergraduate students on factors that influence them to entrepreneurial intentions. Based on literature survey, they identified validated factors used for predicting entrepreneurial intention. A total of 196 valid data were analysed by using Multiple Regressions. The results show that entrepreneurial intention was predicted by the need for achievement, family business background and subjective norms except the desire for independence.

Shiri, Hosseini and Mohammadi (2012) have gone through on the entrepreneurial intention of agricultural students considering four factors namely role model, social support, social norms and perceived desirability. The study also tried to describe the demographic profile of the sampled students in agricultural disciplines in University of Ilam. From the result of Path Analysis Technique of the study, it was found that "perceived desirability" has the most direct impact on entrepreneurial intention of students and factors which are role model, social support and social norms have most indirectly impact through perceived desirability on changing the entrepreneurial intention of the students.

Aslam et al. (2012) in a scholarly article examined the levels of entrepreneurial intentions among the students in Punjab, a province of Pakistan through a model developed by Ajzen. The study has covered 197 Pakistani university students. Data have been analysed using SPSS software while correlation, t-test and regression have been utilized for finding out the results. Results of the study have revealed that students participated in entrepreneurship education have more intention towards entrepreneurship than those who has not participated in entrepreneurship education courses.

Lu et al. (2012) studied on 2010 senior university students from nine universities in Xi'an, China, and the study analyses the students' entrepreneurial intention level and its influencing factors. The results show that the perceived subjective norm of university students has significantly positive influence on their entrepreneurial attitude.

Rasli et al. (2013) empirically assessed the relationship of entrepreneurial intention and its antecedents among graduating university students based on the models developed by Davidsson (1995) and Autio et al. (1997). Variables like work experience, vicarious experience, general attitude, image of entrepreneurship and demography were tested against entrepreneurial conviction and entrepreneurial intentions. The study supports the proposition that conviction is the strongest variable that has direct influence towards entrepreneurial intention, whereas general attitude has a significant influence as well as those male students with work experience were found to have higher entrepreneurial intention. 
Neneh, (2014) in a scholarly article indicated that while university students in Cameroon possess a high intention to become entrepreneurs, there are however, predominantly push factors such as unemployment, poverty and job security that force most university students to engage in various forms of entrepreneurship. Also obstacles such as lack of funding, lack of business skills, bribery and corruption, strong competitors, high taxes, and high labour cost were identified as the main obstacles prohibiting university student's form choosing entrepreneurship as a career choice in Cameroon. It is also observed that there is a significant difference on the level of entrepreneurial intentions based on gender and entrepreneurship education.

Ambad and Damita (2016) investigated the predictors of entrepreneurial intention among undergraduate students. Their study found that, personal attitude have a significant effect on students' intention to become an entrepreneur. Thus, it is suggested that the greater the students' attitude towards the entrepreneurship, the greater the entrepreneurial intention is. Secondly, perceived behavioural control was found to have a significant impact on entrepreneurial intention among the sampled students. Thirdly, perceived relational support is found to have a significant impact on entrepreneurial intention. In other words, the greater the supports from parents, family, friends and people surrounding them, the greater the entrepreneurial their intention is.

Ambad and Damit (2016) studied on the determinants of entrepreneurial intention among undergraduate students in Malaysia. The study aimed to identify the determinants of entrepreneurial intention among 351 undergraduate students in one of the Public University in Malaysia by using Theory of Planned Behaviour (TPB). The independent variables of this study consisted of perceived educational support, perceived relational support, perceived structural support, personal attitude and perceived behavioural control. The study found that personal attitude, perceived behavioural control and perceived relational support are the predictors to entrepreneurial intention.

Job satisfaction Davis and Nestrom (1985) opined that job satisfaction represents a combination of positive or negative feelings that workers have towards their work. Job satisfaction represents the extent to which expectations are and match the real awards. Job satisfaction is closely linked to that individual's behaviour in the work place. Considering the gender differences in job satisfaction, Bhatt (1987) studied the personality determinations of Job satisfaction of college teachers. It was found that female teachers were more satisfied than male teachers; also no significant difference was found in the mean scores of married and unmarried teachers. It was also found that job satisfaction had no significant relation with the age, area of the work, educational qualification and experience. Karl and Sutton (1998) found that from the employees' point of view, job satisfaction is a desirable outcome in itself. While from a managerial or organisational effectiveness point, job satisfaction is important due to its impact on absenteeism and low turnover. Thus, it becomes important for the managers to understand what employees' value in order to redesign jobs, reward systems and human resource management policies that will result in optimum job satisfaction and productivity.

Kaliski (2007) highlighted that job satisfaction is a worker's sense of achievement and success on the job. It is generally perceived to be directly linked to productivity as well as to personal well-being. It further implies enthusiasm and happiness with one's work. It is the 
key ingredient that leads to recognition, income, promotion, and the achievement of other goals that lead to a feeling of fulfilment. In the same measure George et al., 2008 opined that job satisfaction is the collection of feeling and beliefs that people have about their current job. People's levels of degrees of job satisfaction can range from extreme satisfaction to extreme dissatisfaction. In addition to having attitudes about their jobs as a whole, people also can have attitudes about various aspects of their jobs such as the kind of work they do, their co-workers, supervisors or subordinates and their pay. Considering the importance and influencing factors of job satisfaction, Fisher et al., (1992), Xie et al., (2000), Vidal et al., (2007) and Lane et al., (2010), opined that salary, working environment, autonomy, communication and organisational commitment are the influencing factors of job satisfaction. In an scholarly attempt, Khalid (2010) examined job satisfaction among the employees of both public and private sector banks. The findings of the study indicated that the sectoral differences in terms of salary, promotions, job security, recognition and benefits play a significant role in influencing one's perception of job satisfaction. Neog and Barua (2014) studied on the factors influencing employees' job satisfaction among the employees of automobile service workshops in Assam. The study found that salary occupies the most important factor for influencing employee's job satisfaction compared with other major factors. The other factors includes work-family balance, supervisor support and career opportunities. Khalid and Adnan (2009) in a scholarly article mentioned that staff satisfaction is the main internal marketing tool that could contribute to guest satisfaction and the sustainability of the hospitality business. Vijit (2010) opined that emotional or affective commitment is significantly associated with job satisfaction. The paper commented on designing strategies which can help in developing an emotional commitment towards job which may help in retaining employees and enhancing loyalty to the organisation. Considering the importance of human resources in hotel industry, Rajeev (2013) tried to evaluate the human resource practices in the same industry. The study found that the employees are satisfied with the working condition and dissatisfied with their carrier growth. Gupta and Garg (2017) in a research investigation articulated that employees are dissatisfied with the behaviour of supervisor, pay/ salary, promotional opportunities, internal policies and organisational management. Simbat and Almas (2018) in a study highlighted that the quality and social conditions in the business environment of hotel industry are well developed, because the hotel business environment is in the same place as the working environments and customer service environments.

Organisational commitment On the other hand, organisational commitment is also one of the crucial dimensions in the success of any organisation. Mathieu and Zajac (1990) observed that commitment is an attitude reflecting the nature and quality of the linkage between an employee and the organisation. Organisational commitment is the psychological attachment that individuals develop toward an organisation (Fiorito et al., 2007; Wright \& Kehoe, 2007). Raza and Nawaz (2011) highlighted that organisational commitment is stated as the attachment or bonding that individuals form to their employing organisations. In an another scholarly article, Eslami and Gharakhani (2012) opined commitment as a format that seeks to explain consistencies involving attitudes, values, behaviour and involves behavioural choices and implies a negative response of possible alternative courses of action. 
Mathew (1991) examined the relationship between job satisfaction and organisational commitment with a non-recursive model that permitted the simultaneous examination of the influence of satisfaction on commitment and the influence of commitment on satisfaction. The study highlighted that the two variables were reciprocally related but that the influence of satisfaction on commitment was stronger. In the same assessment, Sayeed (1992) made an endeavour to determine the relationship between employee job satisfaction and organisational effectiveness. The main objective of the study was to relate satisfaction with organisational effectiveness along with personal attributes such as age, education, pay, length of service etc. The study revealed that job satisfaction facets had more explanatory power than the personal attributes of respondents. It was clear from the study that the organisation through its human resource development policies and practices created better environment for employees, resulting in greater satisfaction which in turn enhanced organisational effectiveness. Another finding which supports the relationship between job satisfaction and commitment to the organisation can be drawn from the study of Cranny et al. (1992) that reveals that attitudinal factor such as employees' organisational commitment is closely related with job satisfaction where it is a contribution of cognitive and affective reactions to the differential perception of what an employee wants to receive compared with what he or she actually receives. In the light of this notion, Weiner (2000) stated that job satisfaction is dependent on the nature of the job itself, which is integrated with job challenges, autonomy, skill variety and job scope. Thus, nature of job itself is at the top places for researchers in order to understand what makes people to be satisfied with their jobs.

Okpara (2004) propounded that job satisfaction and commitment are primary determinants of employee turnover, performance and productivity. Again, Baron and Greenberg (2005) articulated that job satisfaction among employees is an indicator of organisational effectiveness and it is influenced by organisational and personal factors such as organisational commitment to set goals, workers incentives, job involvement, job commitment and job satisfaction. Ayeni and Phopoola (2007) also found a strong relationship between job satisfaction and organisational commitment. Understanding the importance of job satisfaction in hotel industry, Gunlu, et al. (2009) examined the effect of job satisfaction on organisational commitment for managers in large-scale hotels in the Aegean Region of Turkey. The study examined the significant relationship between the organisational commitment and job satisfaction and found that extrinsic, intrinsic and general job satisfaction had a significant effect on normative and affective commitment. Considering the demographic factors in commitment, Iqbal (2010) investigated the relationship between demographic factors (age, tenure and level of education) and organisational commitment. The results of the analyses showed that length of service is significantly associated with organisational commitment, whereas, education level is negatively correlated with organisational commitment. Furthermore, no significant correlation was found between organisational commitment and age.

Srivastava (2013) aimed to find out the effect of Job satisfaction on organisational commitment. Results of the study have proved that Job Satisfaction is positively related to Organisational Commitment. Ismail and Razak (2016) evaluated the association between job satisfaction and organisational commitment at Fire and Rescue Department of Malaysia. The study discovered that job satisfaction, intrinsic and extrinsic satisfaction was significantly associated with organisational commitment. 
This finding confirms that when employees satisfied with intrinsic and extrinsic satisfaction from his or her job condition may lead to greater organisational commitment in the studied organisations.

Relationship between job satisfaction, organisational commitment and entrepreneurial intention The interplay between job satisfaction, organisational commitment and entrepreneurial intention are drawn below:

\section{Entrepreneurial intention and job satisfaction}

The Push Theory on entrepreneurship argues that people are pushed into entrepreneurial activities by negative situational factors such as dissatisfaction with existing employment. These negative situations tend to activate latent entrepreneurial talent in them and push employees into entrepreneurial activities (Gilad and Levine, 1986). Job satisfaction has been the subject of considerable interest in entrepreneurial research (Brockhaus, 1980; Cromie \& Hayes, 1991; Hisrich \& Brush, 1986). Poor organisational conditions can trigger low job satisfaction, which in turn can trigger the desire to start a business venture. Positive relationships between low job satisfaction and entrepreneurial intentions are well documented within the push theory of entrepreneurship. Frustrated employees are more likely to consider entrepreneurship as an alternative career avenue (Brockhaus, 1980; Cromie \& Hayes, 1991; Henley, 2007). Eisenhauer (1995) reported that individuals are motivated to start their own businesses if the satisfaction from wage employment is lower than the perceived satisfaction possibly derived from self-employment. Studies have recognised that satisfaction from the job foresee entrepreneurial intentions (Eisenhauer, 1995; Watson et al., 1998). Lee et al. (2011) examined the individual's intent to leave their jobs to start.

Business ventures. Findings of the study suggested that work environment with an unfavourable innovation climate and/or lack of technical excellence incentives influence entrepreneurial intention, through low job satisfaction. Tung-Liang (2018) in a study revealed that there is a statistically significant relationship between satisfaction with entrepreneurship education and entrepreneurial intentions. The study also found that satisfaction with entrepreneurship education has a more direct impact on the level of entrepreneurial intention in students.

Jeong and Choi (2017) also examined whether job satisfaction affects entrepreneurial intention. The study concluded that, outcome expectations and self-efficacy had a positive effect on entrepreneurial intention and expected levels of work satisfaction negatively affected the intention to start a business. These findings were also existed in the literature on the previous work of Noorderhaven et al. (2004) and Werner et al. (2014) that shows a negative relationship between job satisfaction and entrepreneurial intention. Individuals who are satisfied with their job have a desire to maintain their job because doing so might provide higher expected utility than self-employment (Trevor (2001). Kahneman and Tversky (1979) highlighted that if individuals' perceived criteria are not met, it is recognised as a loss. When the loss is perceived to be greater than the benefit, the individual will pursue risk-seeking behavior. Low job satisfaction can be interpreted as a loss, which may encourage risk-seeking behavior. Then, people take risky initiatives such as starting a business instead of choosing a stable job. From 
the above reviews, it is found that low job satisfaction is a motivating factor to inculcate entrepreneurial intention to the employees.

\section{Entrepreneurial intention and organisational commitment}

Luca and Simo (2016) in a scholarly article found that organisations impose common aims, objectives, rules, chains of command and control to their employees that drastically limit individual initiative and autonomy. Serinkan et al. (2013) indicated that, even in large organisations, entrepreneurial behaviour in employees is seen as favourable to increase the competitiveness and performance of the employees. Gbadamosi and Nwosu (2011a, b) articulated that entrepreneurial intention and job satisfaction are the significant predictors of organisational commitment. Further, the results of this study revealed that when individual are not satisfied with their job, they have the feelings of psychological contract breach and perceived injustice being present in their workplace. Then, there are tendencies of wanting to leave and not being committed to the organisation and intending to start an enterprise.

\section{Job satisfaction and organisational commitment}

Kovach (1977) stated that, job satisfaction is recognised as a component of organisational commitment, while Porter et al. (1974), Price (1977) and Spector (1997a, b) have clearly stated that job satisfaction is a predictor of organisational commitment. The relationship between job satisfaction and organisational commitment has been existed since the Hawthorne studies (Al-Aameri, 2000). Feinstein and Vondrasek (2001) in a scholarly article analysed the effects of job satisfaction on organisational commitment among restaurant employees and the findings proved that satisfaction levels of the employees can predict their commitment to the organisation. Further, they again opined that commitment is more consistent than job satisfaction over time and lasts longer when one is satisfied with his or her job. Meyer et al. (2002) also stated that job satisfaction is a determinative of organisational commitment and these two variables are highly interrelated. Aizzat et al. (2003) found that organisational commitment has a direct relationship with employees' satisfaction level towards pay, promotion system, work, supervision and co-workers. The study concluded that promotion system is the most important factor influencing an employee's commitment level. Again, Kotze and Roodt (2005) articulated that a strong positive correlation has been empirically established between job satisfaction and organisational commitment. This literally means that when the employees' level of satisfaction improves, then levels of organisational commitment would develop too.

Based on the foregoing discussions, the following research questions have been framed to enable the paper to focus on the argument of the same.

i. Is there any significant relationship between job satisfaction and organisational commitment?

ii. Is there any significant relationship between job satisfaction and entrepreneurial intention?

iii. Is there any significant relationship between organisational commitment and entrepreneurial intention? 


\section{The construct of the research model}

In the words of Lumley et al. (2011) it is mentioned that satisfied employees tend to be committed to an organisation and employees who are satisfied and committed are more likely to attend work, stay with the organisation, arrive at work on time, perform well and engage in behaviours helpful to the organisation. Mohamed et al. (2012) found out that job satisfaction is positively related to organisational trust, affective commitment, continuance commitment and normative commitment. Job satisfaction and organisational commitment are interrelated to each other (Daneshfard \& Ekvaniyan, 2012). In a study conducted by Dirani and Kuchinke (2011) on the relationship between job satisfaction and organisational commitment, it is concluded that job satisfaction and organisational commitment were significantly correlated and satisfaction was a predictor of commitment. There is a direct link between job satisfaction and organisational commitment (Williams \& Hazer, 1986; Aydogdu \& Asikgil, 2011; Suma \& Lesha, 2013).

The application of Theory of Planned Behaviour (TPB) has been recorded in the studies of Do Paço et al. (2011), Fini et al. (2009), Kautonen et al. (2009, 2010), Mariano et al. (2011) and Sommer and Haug (2011). TPB is indeed a good and useful model to explain entrepreneurial intention. However, extending the basic model of TPB by adding in new variables does make sense (Sommer \& Haug, 2011; Van Gelderen et al. 2008). In the present paper, Job Satisfaction and Organisational Commitment are the two variables in addition to Entrepreneurial Intention. In addition to descriptive statistics, Pearson Correlation Co-efficient and Path Analysis can be used to measure entrepreneurial intention. The following Fig. 3 illustrates the model constructed in this paper.

Based on the said model, the following hypotheses are framed for those studies that might adopt the model.

$\mathrm{H}_{1}$ - There is a significant relationship between job satisfaction and organisational commitment.

$\mathrm{H}_{2}$ - There is a significant relationship between job satisfaction and entrepreneurial intention.

$\mathrm{H}_{3}$ - There is a significant relationship between organisational commitment and entrepreneurial intention.

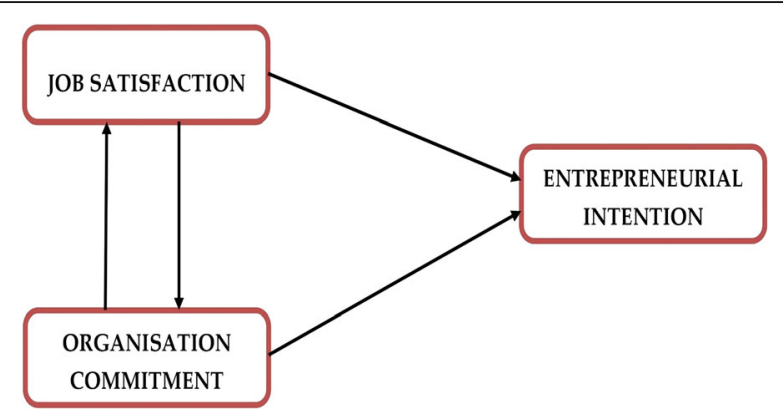

Fig. 3 Research model. Source: Developed by the Researchers. Singh, K. D. \& Onahring B. D. (2018), Entrepreneurial Intention, Job Satisfaction and Organisation Commitment - Construct of a Research Model through Literature Review, Unpublished Article 


\section{Conclusion}

This paper is only to develop a research model on the relationship between entrepreneurial intention, job satisfaction and organisational commitment. Some relevant hypotheses were also framed based on the developed research model. Both the research model and hypotheses might be useful to study the relationship between the three above mentioned variables.

\section{Abbreviations \\ TPB: Theory of Planned Behaviour; TRA: Theory of Reasoned Action}

\section{Acknowledgements}

Not applicable.

Funding

The authors have no research funding to be declared.

\section{Availability of data and materials}

Not applicable.

\section{Authors' contributions}

Both the authors have contributed equally in finalizing this manuscript and both has read and approved the final manuscript.

\section{Competing interests}

The authors declare that they have no competing interests.

\section{Publisher's Note}

Springer Nature remains neutral with regard to jurisdictional claims in published maps and institutional affiliations.

Received: 23 July 2018 Accepted: 4 December 2018

Published online: 21 January 2019

\section{References}

Adams, J. S. (1963). Wage inequalities. productivity and work quality. Industrial Relations, 3, 9-16.

Aizzat, M. N., Ramayah, T., Mohamad, A. H., \& Seow, L. V. (2003). Job satisfaction and turnover intentions: A study among academicians. The Proceedings of the 5th Asian Academy of Management Conference, "Challenges of Globalized Business: The Asian Perspective", 10th - 13th September (p. 2003). Kuantan, Pahang: Hyatt Hotel.

Ajzen, I. (1985). From intentions to actions: A theory of planned behavior. In J. Kuhl \& J. Beckman (Eds.), Actioncontrol: From cognition to behavior (pp. 11-39). Heidelberg. Germany: Springer.

Ajzen, I. (1991). Theory of planned behaviour. Organisational Behaviour and Human Decision Processes, 50(2), $179-211$.

Al-Aameri, A. S. (2000). Job satisfaction and organisational commitment for nurses. Saudi Medical Journal, 21(6), 531-535.

Ambad, S. N. A., \& Damita, D. H. D. A. (2016). Determinants of entrepreneurial intention among undergraduate students in Malaysia. Procedia Economics and Finance, 37, 108-114.

Aslam, T. M., Awan, A. S., \& Khan, T. M. (2012). Entrepreneurial intentions among university students of Punjab a province of Pakistan. International Journal of Humanities and Socialscience, 2(14), 114-120.

Autio, E., Keeley, R. H., Klofsten, M. \& Ulfdtedt, T. (1997). Entrepreneurial intent among students: Testing an intent model in Asia, Scandinavia, and USA. Frontier of Entrepreneurship Research.

Aydogdu, S., \& Asikgil, B. (2011). An empirical study of the relationship among job satisfaction, organizational commitment and turnover intention. International Review of Management and Marketing, 1(3), 43.

Ayeni, C. O., \& Phopoola, S. O. (2007). Work motivation, job satisfaction, and organisational commitment of library personnel in academic and research libraries in Oyo state. Nigeria, Library Philosophy and Practice, 366-376.

Azjen, I., \& Madden, T. (1986). Prediction of goal-directed behaviour: Attitudes, intentions and perceived behavioural control. Journal of Experimental Social Psychology, 22(5), 453-474.

Bagozzi, B., \& Bluedorn, R. (1989). The relationship between corporate entrepreneurship and entrepreneurial intention. Strategic Management Journal, 20, 21-44.

Baron, R. A., \& Greenberg, J. (2005). Behaviour in organisation (7th ed.). New Jersey: Prentice Hall.

Becker, H. S. (1960). Notes on the concept of commitment. American Journal of Sociology, 66, 32-40.

Bhatt, D. J. (1987). Personality determinations of job-satisfaction of college teachers in Saurashtra Region of Gujarat? Unpublished Ph.D. Thesis. Bhavnagar: Bhavnagar University.

Bird, B. (1988). Implementing entrepreneurial ideas: The case for intention. Academy of Management Review, 13(3), $442-453$.

Brockhaus, R. H. (1980). The effect of job dissatisfaction on the decision to start a business. Journal of Small Business Management., 18, 37-43.

Burke, P. J., \& Stets, J. E. (1998). Identity theory and social identity theory. American Sociological Association, Social Psychology Quarterly, 63(3), 224-237.

Carlson, S. D. (1985). Consistency of attitude components: a new approach for all problems. Dissertation abstract international, 46(09B), 32-61. 
Caught, K., \& Shadur. (2000). The measurement artifact in the organisational commitment questionnaire. Psychological Reports, $87,777-788$.

Colman, A. (2015). Theory of reasoned action a dictionary of psychology. London: Oxford University Press.

Cranny, C. J., Smith, P. C., \& Stone, E. F. (1992). Job satisfaction: How people feel about their jobs and how it affects their performance. New York: Lexington Books.

Cromie, S., \& Hayes, J. (1991). Business ownership as a means of overcoming job dissatisfaction. Personnel Review., 20(1), 19-24.

Daneshfard, C., \& Ekvaniyan, K. E. (2012). Organizational commitment and job satisfaction in Islamic Azad University. Interdisciplinary Journal of Contemporary Research in Business, 3(9), 168-181.

Davidsson, P. (1995). Determinant of entrepreneurial intentions. RENT IX workshop in entrepreneurship research. Piacenza: Swedish Foundation for Small Business Research.

Davis, K., \& Nestrom, J. W. (1985). Human behavior at work: Organisational behavior (7th ed.p. 109). New York: McGraw Hill.

Dell, M. S. (2008). An investigation of undergraduate student self-employment intention and the impact of entrepreneurship education and previous entrepreneurial experience. The Australia: Doctor of Philosophy, School of Business University.

Dirani, K. M., \& Kuchinke, K. P. (2011). Job satisfaction and organizational commitment: Validating the Arabic satisfaction and commitment questionnaire (ASCQ), testing the correlations, and investigating the effects of demographic variables in the Lebanese banking sector. The International Journal of Human Resource Management, 22(05), 1180-1202.

Do Paço, A. M. F., Ferreira, J. M., Raposo, M., Rodrigues, R. G., \& Dinis, A. (2011). Behaviors and entrepreneurial intention: Empirical findings about secondary students. Journal of International Entrepreneurship, 9, 20-38.

Dohse, D., \& Walter, S. G. (2010). The role of entrepreneurship education and regional context informing entrepreneurial intentions. Working Paper present at Document de treball de I IEB2010/18.

Doswell, W., et al. (2011). Testing the theory of reasoned action in explaining sexual behaviour among African American young teen girls. Journal of Paediatric Nurshing, 26(6), 45-54.

Eisenhauer, J. G. (1995). The entrepreneurial decision: Economic theory and empirical evidence. Entrepreneurship Theory and Practice, 19(4), 67-80.

Eslami, J., \& Gharakhani, D. (2012). Organisational commitment and job satisfaction. ARPN Journal of Science and Technology, 2(2), 85-91.

Feinstein, A. H., \& Vondrasek, D. (2001). A study of relationships between job satisfaction and organisational commitment among restaurant employees. Journal of Hospitality, Tourism, and Leisure Science, 29(2), 5-21.

Fini, R., Grimaldi, R., Marzocchi, G. L., \& Sobrero, M. (2009). The foundation of entrepreneurial intention, conference proceedings in summer conference 2009, June 17-19, 2009. Frederiksberg: Druid Press.

Fiorito, J., Bozeman, D. P., Young, A., \& Meurs, J. A. (2007). Organisational commitment, human resource practices, and organisational characteristics. Journal of Managerial Issues, 19(2), 186-207.

Fishbein, M., \& Ajzen, I. (1975). Belief, attitude, intention and behavior: An intro- duction to theory and research. Reading, MA: Addison-Wesley.

Fisher, C. D., \& Locke, E. A. (1992). The new look in job satisfaction research and theory. In C. J. Cranny, P. C. Smith, \& E. F. Stone (Eds.), Job satisfaction: How people feel about their jobs and how it affects their performance (pp. 165-194). NY: Lexington Books.

Gbadamosi, L., \& Nwosu, C. (2011b). Organisational politics, turnover intention and organisational commitment as predictors of employees' efficiency and effectiveness in academia. In LasunGbadamosi Department of Educational Foundation \& Management, OlabisiOnabanjo University, ago-iwoye. Ogun State: Informing Science Institute.

Gbadamosi L., Nwosu J.C., (2011a). Entrepreneurial intention, organisational justice and job satisfaction as determinants of employees' organizational commitment: evidence from Babcock University Nigeria. Proceedings of Informing Science \& IT Education Conference (InSITE), 210.

Gelderen, M. V., et al. (2008). Explaining entrepreneurial intentions by means of the theory of planned behaviour. Career Development International, 13(6), 538-559.

George, J. M., \& Jones, G. R. (2008). Understanding and Managing Organizational Behaviour, Fifth Edition (p. 78). New Yersey: Pearson/Prentice Hall.

Gilad, B. \& Levine, P. (1986). A behavioral model of entrepreneurial supply. Journal of Small Business Management, 24, 45-53.

Gordon, A. W. \& Odbert, H. S. (1936). Trait-names: A psycho-lexical study. Psychological Monographs, 47 (1), i-171.

Gunlu, E., Aksarayli, M., \& Percin, N. S. (2009). Job satisfaction and organisational commitment of hotel managers in Turkey. International Journal of Contemporany Hospitality Management, 22(5), 693-717.

Gupta, K., \& Garg, I. (2017). Investigation of job satisfaction among employees: A case of hospitality industry in Ambala (India), Voice of Research, 6(1), 50-56.

Hackman, J. R., \& Odham, G. R. (1976). Motivation through the design of work: Test of a theory. organisational behaviour and human performance, 16, 260-279.

Henley, A. (2007). Entrepreneurial aspiration and transition into self-employment: Evidence from British longitudinal data. Entrepreneurship and Regional Development, 19(3), 253-280.

Hisrich, R. D., \& Brush, C. (1986). Characteristics of the minority entrepreneur. Journal of Small Business Management, 24, 1-8.

Hoppock, R. (1935). Job satisfaction. New York: Harper and Brothers.

lqbal, A. (2010). An empirical assessment of demographic factors, organisational ranks and organisational commitment. International Journal of Business and Management, 5(3), 161-166.

Ismail, A., \& Razak, M. R. A. B. D. (2016). Effect of job satisfaction on organisational commitment. Management \& Marketing, XIV(1), 25-40.

Ismail, M., Khalid, et al. (2009). Entrepreneurial intention among Malaysian undergraduates. International of Business and Management, 4(10), 54-60.

Jeong, J., \& Choi, M. (2017). The expected job satisfaction affecting entrepreneurial intention as career choice in the cultural and artistic industry. MDPI Journal of Sustainability, 9, 2-16.

Kahneman, D.. \& Tversky, A. (1979). Prospect theory: An analysis of decisions under risk. Econometrika, 47, 263-229.

Kaliski, B. S. (2007). Encyclopedia of Business and Finance (Vol. 446, 2nd ed.). Detroit: Thompson Gale.

Karl, K. A., \& Sutton, C. L. (1998). Job values in today's workforce: A comparison of public and private sector employees. Public Personnel Management, 27(4), 515-527. 
Kassin, S. (2003). Psychology. USA: Prentice Hall, Inc..

Katono, I. W., Heintze, A., \& Byabashaija, W. (2010). Environmental factors and graduate start up in Uganda. Paper presented at the Conference on Entrepreneurship in Africa. New York: Whitman School of Management, Syracuse University.

Katz, J., \& Gartner, W. (1988). Properties of emerging organisations. Academic of Management Review, 13, 429-441.

Kautonen, T., Luoto, S., \& Tornikoski, E. T. (2010). Influence of work history on entrepreneurial intentions in 'prime age' and 'third age': A preliminary study. International Small Business Journal, 28(6), 583-601.

Kautonen, T., Tornikoski, E.T. and Kibler, E. (2009). Entrepreneurial intentions in the third age: The impact of perceived age norms, small business economics, published online 18 October 2009.

Khalid, M., \& Adnan, A. S. (2009). The implications of hotel employee satisfaction in promoting quality tourism at the cultural heritage site of Petra-Jordan. TEAM Journal of Hospitality \& Tourism, 6(1), 36-45.

Khalid, S. (2010). Job satisfaction among bank employees in Punjab, Pakistan: A comparative study. Journal of Social Science, 17(4), 570-577.

Kotze, K., \& Roodt, G. (2005). Factors that affect the retention of managerial and specialist staff: An exploratory study of an employee commitment model. South African Journal of Human Resource Management, 3(2), 48-55.

Kovach, K. (1977). Organization size, job satisfaction, absenteeism, and turnover. Washington, DC: University Press of America.

Krueger, F. N. (2007). What lies beneath? The experiential essence of entrepreneurial thinking. Entrepreneurship Theory and Practice, 31(1), 123-138.

Krueger, N. F., Jr., Reilly, M. D., \& Carsrud, A. L. (2000). Competing model of entrepreneurial intentions. Journal of Business Venturing, 15(5-6), 411-432.

Lane, K. A., Esser, J., Holte, B., \& McCuskar, M. A. (2010). A study of nurse faculty job satisfaction in community colleges in Florida. Teaching and Learning in Nursing, 5, 16-26.

Lee, L., Wong, P. K., Foo, M. D., \& Leung, M. (2011). Entrepreneurial intentions: The influence of organizational and individual factors. Journal of Business Venturing, 26, 124-136.

Locke, E. A. (1968). Toward a theory of task motivation and incentives. Organizational Behavior and Human Performance, 3(2), 157-189.

Lu, H., Barriball, K. L., Zhang, X., \& While, A. E. (2012). Job satisfaction among hospital nurses revisited: A systematic review. International Journal of Nursing Studies, 49, 10-17.

Luca M.R \& Simo A.M (2016). Entrepreneurial traits and work satisfaction. Bulletin of the Transilvania University of Braşov, Special Issue Series VII, social sciences, law, 9 (58)1.

Lumley, E. J., Coetzee, M., Tladinyane, R., \& Ferreira, N. (2011). Exploring the job satisfaction and organisational commitment of employees in the information technology environment. Southern African Business Review, 15(1), 100-118.

Luthans, F. (2005). Organisational Behaviour (10th ed.). Boston: McGraw-Hill.

Mathew, J. E. (1991). Ma cross level non recursive model of the antecedents of organisational commitment and satisfaction. Journal of Applied Psychology, 76(5), 607-661.

Mathieu, J., \& Zajac, D. (1990). A review and meta analysis of the antecedents, correlates and consequences of organisational commitment. Psychology Bulletin, 108, 171-194.

McClelland, D. C. (1961). The achieving society. N. J., Van Nostrand: Princeton.

Meyer, J. P., Stanley, D. J., Herscovitch, L., \& Topolnytsky, L. (2002). Affective, continuance, and normative commitment to the organization: A meta-analysis of antecedents, correlates, and consequences. Journal of Vocational Behavior, 61(1), $20-52$.

Miller, D., \& Lee, J. (2001). The people make the process: Commitment to employees, decision making, and performance. Journal of Management, 27, 163-189.

Miller, G. A. (2003). The cognitive revolution: A historical perspective. Trends in Cognitive Sciences, 7(3), 141-144.

Mohamed, M. S., Kader, M. M. A., \& Anisa, H. (2012). Relationship among organisational commitment, trust and job satisfaction: An empirical study in banking industry. Research Journal of Management Sciences, 1(2), 1-7.

Moriano, J. A., Gorgievski, M., Laguna, M., Stephan, U. \& Zarafshani, K. (2011). A cross-cultural approach to understanding entrepreneurial intention, journal of career development, published online 6 January 2011.

Neneh, B. N. (2014). An assessment of entrepreneurial intention among university students in Cameroon. Mediterranean Journal of Social Sciences, 5(20), 542-552.

Neog, B. B., \& Barua, M. (2014). Factors influencing employee's job satisfaction: An empirical study among employees of automobile service workshops in Assam. The Standard International Journals on Industrial, Financial \& Business Management, 2(7), 305-316.

Noorderhaven, N., Thurik, R., Wennekers, S., \& Stel, A. V. (2004). The role of dissatisfaction and per capita income in explaining self-employment across 15 European countries. Entrepreneur Theory Practical, 28, 447-466.

Okpara, J. O. (2004). Job satisfaction and organisational commitment: Are there differences between American and Nigerian managers employed in the US MNCs in Nigeria? In Academy of Business \& Administrative Sciences. Switzerland: Rrittrcliffe College.

Perry, N. E., Phillips, L., \& Hutchinson, L. R. (2006). Preparing student teachers to support for self-regulated learning. Elementary School Journal, 106, 237-254.

Porter, L., Steers, R., Mowday, R., \& Boulian, P. (1974). Organizational commitment, job satisfaction, and turnover among psychiatric technicians. Journal of Applied Psychology, 59(5), 603-609.

Powell, D. M., \& Meyer, J. P. (2004). Side-bet theory and the three-component model of organisational commitment. Journal of Vocational Behaviour, 65, 157-177.

Price, J. (1977). The study of turnover. Ames: lowa State University press.

Rajeev, S. (2013). A study of hotel industry to find job satisfaction through HRM practices. International Journal of Science \& Research, 4(4), 1533-1536.

Rasli, A. M., Khan, S. R., Malekifar, S., \& Jabeen, S. (2013). Factors affecting entrepreneurial intention among graduate students of university Teknologi Malaysia. International Journal of Business and Social Science, 4(2), 182-188.

Raza, M. A., \& Nawaz, M. (2011). Impact of job enlargement on employees' job satisfaction, motivation and organisational commitment: Evidence from public sector of Pakistan. International Journal of Business and Social Science., 2(18), 268-273.

Remeikiene R. D. and Startiene G. (2013). Explaining entrepreneurial intention of university students: The role of entrepreneurial education. International proceedings of the management, knowledge and learning international conference 2013. 299-307. 
Robbins, S.P. (2005) Organisational Behaviour (11th ed.) New Jersey: Pearson Education, Inc.423. De Dreu, C. \& Van de Vliert E. (1997) Using Conflct in companies, London: Sage Publications.

Rogers, G. M., et al. (2002). Teen sexual behaviour: Applicability of the theory of reasoned action. Journal of Marriage and Family, 64(4), 885-897.

Sayeed, O. B. (1992). Organisational effectiveness-relationship with job application. New Delhi: Sage Publications.

Serinkan, C., Kaymakçi, K., Arat, G., \& Avcik, C. (2013). An empirical study on intrapreneurship: In a service sector in Turkey. Procedia - Social and Behavioral Sciences, 89, 715-719.

Shajahan, D. S., \& Shajahan, L. (2004). Organisation Behaviour. New Delhi: New age international publications.

Shiri, N., Mohammadi, D., \& Hosseini, S. M. (2012). Entrepreneurial intention of agricultural students: effects of role model, social support, social norms and perceived desirability. Archives of Applied Science Research, 4(2), 892-897.

Simbat, N., \& Almas, K. (2018). Methodical aspects of job satisfaction measure of employees in hotel business quality improvement in Kazakhstan. African Journal of Hospitality, Tourism and Leisure, 7(3), 1-12.

Singh, K. D. \& Onahring B. D. (2018). Entrepreneurial intention, job satisfaction and organisation commitment - construct of a research model through literature review, Unpublished Article.

Singhai, M. (2016). International science community association. Mini Review Paper,, Research Journal of Management, 5(9), 66-68.

Sommer, L., \& Haug, M. (2011). Intention as a cognitive antecedent to international entrepreneurship: Understanding the moderating roles of knowledge and experience. International Entrepreneurship Management Journal, 7, 111-142.

Spector, P. (1997a). Application, assessment, cause, and consequences. Thousand Oaks, CA: Sage Publications, Inc.

Spector, P. E. (1997b). Job satisfaction: Application, assessment, causes and consequences. Thousand oaks, CA: Sage publications, Inc.

Srivastava, S. (2013). Job satisfaction and organisational commitment relationship: Effect of personality variables. Vision-Journal of Business Perspective, 17(2), 21-30.

Statt, D. (2004). The Routledge Dictionary of Business Management (Vol. 78, 3rd ed.). Detroit: Routledge Publishing.

Suma, S., \& Lesha, J. (2013). Job satisfaction and organisational commitment: The case of shkodra municipality. European Scientific Journal, 9(17), 41-51.

Swailes, S. (2002). Organisational commitment: A critique of the construct and measures. International Journal of Management Reviews, 4(2), 155-178.

Tajfel, H. (1970). Experiments in intergroup discrimination. Scientific American, 223(5), 96-102.

Tong, X. F., Tong, D. Y. K., \& Loy, L. C. (2011). Factors influencing entrepreneurial intention among university students. International Journal of Social Sciences and Humanity Studies, 3(1), 487-496.

Trevor, C. (2001). Interactive effects among actual ease of movement determinants and job satisfaction in the prediction of voluntary turnover. Academy of Management Journal, 44(4), 621-638.

Tung-Liang, H. (2018). Satisfaction with entrepreneurial education and entrepreneurial intention: The moderating role of internal locus of control. International Journal of Education and Research, 6(4), 139-146.

Turker, D., \& Senem, S. S. (2009). Which factors affect entrepreneurial intention of university students? Journal of European Industrial Training, 33(2), 142-159.

Turner, J. C., Oakes, P. J., Haslam, S. A., \& McGarty, C. A. (1994). Self and collective: Cognition and social context. Personality and Social Psychology Bulletin, 20, 454-463.

Vidal, M. E. S., Valle, R. S., \& Aragon, B. M. I. (2007). Antecedents of repatriates' job satisfaction and its influence on turnover intentions: Evidence from Spanish repatriated managers. Journal of Business Research, 60, 1272-1281.

Vijit, C. (2010). A study on factors affecting job satisfaction of employees in hotel industry: A study with reference to few categorized hotels in NCR. Management Prudence Journal, 1(2), 40-51.

Vroom, V. H. (1964). Work and motivation. New York: John Wiley and Sons.

Watson, K., Hogarth-Scott, S., \& Wilson, N. (1998). Small business start-ups: Success factors and support implications. International Journal of Entrepreneurial Behavior and Research, 4(3), 217-238.

Weiner, B. (2000). Intrapersonal and interpersonal theories of motivation from an attribution perspective. Educational Psychology Review, 12(1), 1-14.

Werner, A., Gast, J., \& Kraus, S. (2014). The effect of working time preferences and fair wage perceptions on entrepreneurial intentions among employees. Small Business Economic, 43, 137-160.

Williams, L. J., \& Hazer, J. T. (1986). Antecedents and consequences of satisfaction and commitment in turnover models: A reanalysis using latent variable structural equation methods. Journal of Applied Psychology, 71, 219-231.

Wright, P. M., \& Kehoe, R. R. (2007). Human resource practices and organisational commitment: A deeper examination. Asia Pacific Journal of Human Resources, 46(1), 6.

Xie, J. L., \& Johns, G. (2000). Interactive effects of absence culture salience and group cohesiveness: A multi-level and cross-level analysis of work absenteeism in the Chinese context. Journal of Occupational and Organisational Psychology, 73, 31-37. 